\title{
Characterization of Surface Runoff, Soil Erosion and Nutrient Loss on Forest-Agriculture Landscape
}

\author{
Yayat Hidayat*, Kukuh Murtilaksono and Naik Sinukaban \\ Soil Science and Land Resources Department, Faculty of Agriculture, Bogor Agricultural University, Bogor, \\ Indonesia. *Coresponding author, e-mail: yahida@ipb.ac.id
}

Received 20 November 2011/ accepted 6 September 2012

\begin{abstract}
The study was aimed to quantify volume of surface runoff, soil erosion and nutrient loss from the forest-agriculture landscape (forest margins) in Lore Lindu National Park Central Sulawesi. Surface runoff volume and soil erosion were measured daily on erosion plots. It was installed on several land use types i.e. forest land, maize, young cocoa, medium cocoa, old cocoa, vanilla, shrub and bush and bareland, on the soil Typic Dystrudepts with slope \pm $40 \%$. The nutrient content in surface runoff and sediments were analyzed from selected surface runoff and sediment samples. Surface runoff and soil erosion from agriculture land were respectively 2.1 to 3.4 and 3.6 to 5.8 times higher than from forest lands. Meanwhile, surface runoff and soil erosion from bareland were respectively 7.0 and 23.7 times greater than forest land respectively. Sediment nutrient contents from forest land were higher than agriculture land. In the contrary, total nutrient lost from agriculture land were higher than forest land ones. Nutrient losses carried by surface runoff were larger than those losses carried by sediments. Dissolved organic carbon (DOC) loss in surface runoff was 6,1 to 8,0 times higher than total organic carbon (TOC) loss in sediments. Likewise, nitrate (NO3) loss in surface runoff was 1.9 to 12.1 times higher than total nitrogen (TN) in sediments as well as potassium, calcium, magnesium and sodium losses. Potassium is dominant cation loss carried by the surface runoff, while calcium is mainly carried by sediment.
\end{abstract}

Keywords: Dissolve organic carbon, forest-agriculture landscape, nutrient loss, soil erosion, surface runoff

\section{INTRODUCTION}

Nutrients loss due to surface runoff and soil erosion carried away from agriculture land is the main cause of soil degradation of agriculture land, particularly on conventionally land management (Bertol et al. 2003) and steep slope. Nitrogen, phosphorus, organic carbon, potassium, calcium, magnesium and sodium are the main nutrients loss carried by overland flow and soil erosion (Mello 2002 cited by Bertol et al. 2003).

Loss of nutrients can be expressed in terms of nutrient concentrations in surface runoff and transported sediment, or total nutrients loss carried by surface runoff and soil erosion per unit of time (days, seasonal or annual rain). The amount of nutrient loss is influenced by soil type and soil fertility, type fertilizer and application methods, crop canopy cover, slope, and rainfall volume and intensity (Gascho et al. 1998), as well as soil and crop managements (Barisas et al. 1978).

J Trop Soils, Vol. 17, No. 3, 2012: 259-266

ISSN 0852-257X
Conventional land management is usually conducted by clearing weeds and litter of plants, hoeing and smoothing the soils, so that conventionally cultivated lands are characterized by clean, flat and smooth of soil surfaces. Conservation tillage is distinguished by conventional tillage due to presence of litter and crop residues in the soil surface and higher of surface roughness. Therefore the rate of surface runoff and soil erosion can be reduced, and nutrients loss will be lower in conservation tillage systems (King et al. 1996).

Loss of nutrients are expected to be reduced by tillage systems and crop management that retain crop residues on soil surface. But, crop residues and decomposed litters can be flush (Burwell et al. 1975) and dissolved nutrients can be carried away by surface runoff and soil erosion (Barisas et al. 1978; Johnson et al. 1979). Similarly most of the nutrients (especially potassium) that resulted from burned crop residues and other vegetations on cultivation system will disappear and is carried by surface runoff and soil erosion.

The research was aimed to quantify volume of surface runoff, soil erosion and nutrients loss from 
the forest-agriculture landscape of Lore Lindu National Park, Central Sulawesi.

\section{MATERIALS AND METHODS}

\section{Study Site}

Descriptive field research (non-experimental design) was conducted to measure surface runoff volume, soil erosion and nutrient loss from several land use types, which were located on an agricultureforest landscape of Lore Lindu National Park. Administratively research sites was located in Bulili village, Palolo Subdistrict, Central Sulawesi.

\section{Data Collected}

Surface runoff and soil erosion were measured daily volume of surface runoff and amount of eroded soil were collected in the tank at down end of erosion plot. The erosion plots were constructed on a $40 \%$ slope and several landuse types namely forest, maize, maize + peanut, young cocoa, medium cocoa, old cocoa, young cocoa + banana, young cocoa + maize + cassava, vanilla, shrub and bush, reed (Imperata Cylindrica), and bareland. The content of nutrients that were carried by surface runoff and soil erosion were analyzed from selected surface runoff and sediment samples that were collected from July 2004 to May 2005.

\section{Soil Analysis}

Analysis of soil physical properties were conducted in the laboratory of Department of Soil Science and Land Resources, Bogor Agricultural University, while soil and sediment chemical characteristics (organic carbon, total nitrogen, exchangeable of calcium $(\mathrm{Ca})$, potasium $(\mathrm{K})$, magnesium $(\mathrm{Mg})$ and sodium $(\mathrm{Na}))$, nutrients content in surface runoff $\left(\mathrm{NO}_{3}^{-}\right.$, dissolve organic and inorganic carbons, calsium $(\mathrm{Ca})$, potasium $(\mathrm{K})$, magnecium $(\mathrm{Mg})$ and sodium $(\mathrm{Na})$ ) were analyzed in the Laboratory of STORMA-UNTAD, Faculty of Agriculture, University of Tadulako. Types and methods of analysis are presented in Table 1.

\section{Data Analysis}

Data were analysed descriptively by comparing measured data between land use types. Statistically, a pairwise comparison test (Sudjana 1992) was used to identify significant level of daily data of surface runoff volume and soil erosion.

\section{RESULTS AND DISCUSSION}

\section{Surface Runoff and Soil Erosion}

Surface runoff and soil erosion from agriculture land were higher than forest land. Surface runoff from young cocoa, medium cocoa, old cocoa, maize, maize + bean, young cocoa + banana, young cocoa + cassava, cocoa + maize + cassava, shrubs and bush, and reeds (Imperata cylindrica) were 2.1 to 3.4 times greater than the surface runoff from forest lands. While surface runoff volume of bareland could reach 7 times greater than forest land. Soil erosion from agriculture land and bareland were 3.6 to 5.8 and 23.7 times higher than forest land, respectively (Table 2). The results of pairwise comparison test $(n=72$, á $=0.1)$ showed that daily surface runoff volume and soil erosion were significantly different between land use types. Daily surface runoff volume and soil erosion on young cocoa were significantly different than medium cocoa, even though values of accumulated data from September 2004 to May 2005 seemed hardly different.

Low rainfall interception due to low plant canopy cover and low infiltration rate on agriculture land were the major cause of high surface runoff. The increase of surface runoff volume and the increase of sediment transfort capacity were liniarly correlated so that resulting higher soil erosion on agriculture land. Rainfall interception on agriculture land that ranged between $8.4 \%$ (maize) to $10.7 \%$ (medium cocoa) were lower than forest land one

Table 1. Types of analysis and method for the soil, sediment, and surface runoff analysis.

\begin{tabular}{lcc}
\hline Type of Analysis & Type of Sample & Analysis Method \\
\hline Organic carbon & Soil, Sediment & Walkley-Black (dichromate), titration \\
Total nitrogen & Soil, Sediment & Micro-Kjeldahl, titration \\
Exchangeable $\mathrm{Ca}, \mathrm{Mg}, \mathrm{K}$, and $\mathrm{Na}$ & Soil, Sediment & $\mathrm{NH}_{4} \mathrm{OAc} \mathrm{pH}$, AAS \\
$\left.\mathrm{N}^{-\mathrm{NO}_{3}}{ }^{-}\right)$ & Surface runoff & CFA (continous flow analysis) \\
$\mathrm{DIC}($ dissolve inorganic carbon $)$ & Surface runoff & $\mathrm{CFA}$ \\
$\mathrm{DOC}($ dissolve organic carbon $)$ & Surface runoff & $\mathrm{CFA}$ \\
$\mathrm{Ca}, \mathrm{Mg}, \mathrm{K}, \mathrm{Na}$ & Surface runoff & ICP \\
\hline
\end{tabular}


Table 2. Surface runoff and soil erosion from agriculture and forest lands on Typic Eutrudepts, slope $40 \%$ and rainfall 1,696 $\mathrm{mm}$ (Hidayat et al. 2010).

\begin{tabular}{lccccc}
\hline \multirow{2}{*}{ Landuses } & \multicolumn{2}{c}{ Surface runoff } & & \multicolumn{2}{c}{ Soil erosion } \\
\cline { 2 - 3 } \cline { 5 - 6 } & $\mathrm{mm}$ & $\mathrm{CtNF}$ & & $\mathrm{kg} \mathrm{ha}^{-1}$ & $\mathrm{CtNF}^{*}$ \\
\hline Natural forest & 31.1 & - & 288.6 & - \\
Bareland (clean weeded) & 216.2 & 7.0 & 6826.6 & 23.7 \\
Young cocoa & 104.3 & 3.4 & 1674.0 & 5.8 \\
Medium cocoa & 103.9 & 3.3 & 1391.3 & 4.8 \\
Old cocoa & 68.7 & 2.2 & 1543.8 & 5.3 \\
Maize & 66.2 & 2.1 & 1548.0 & 5.4 \\
Maize + peanut & 65.7 & 2.1 & & 1690.7 & 5.9 \\
Young cocoa + banana & 87.0 & 2.8 & & 1317.5 & 4.6 \\
Young cocoa + cassava & 79.5 & 2.6 & & 1561.7 & 5.4 \\
Young cocoa + maize + cassava & 81.6 & 2.6 & 1551.4 & 5.4 \\
Shurbs & 72.1 & 2.3 & 1140.4 & 4.0 \\
Reeds (Imperata cylindrica) & 66.2 & 2.1 & 1048.6 & 3.6 \\
\hline
\end{tabular}

*CtNF: Compared to natural forest (factor higher).

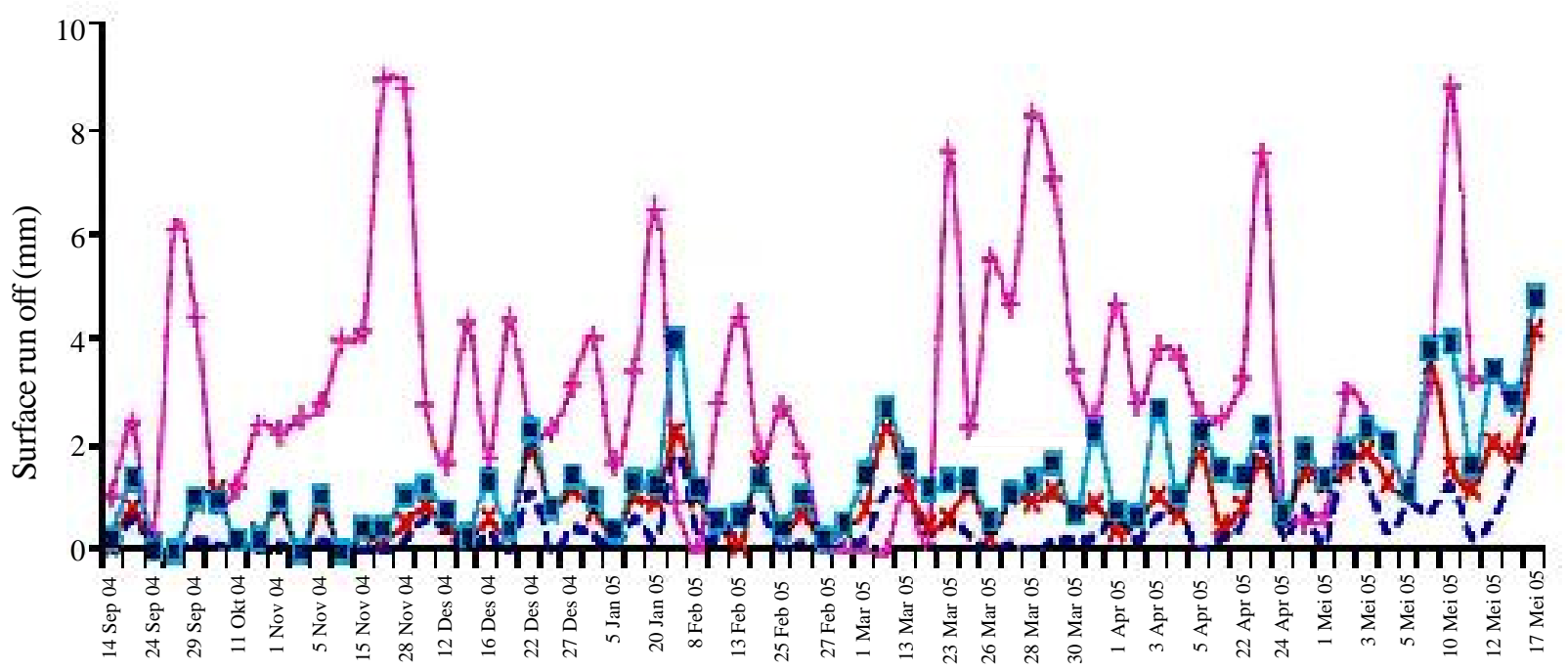

Figure 1. Surface run off from forest, bareland, intercroping maize + peanut, and cocoa September 2004-May 2005). - - - = forest, $\longrightarrow+\square=$ bareland, $\longrightarrow$ - $=$ intercrop maize + peanut, and $\longrightarrow-=$ cocoa.

(28.5\%) (Hidayat 2009). Infiltration rate of forest land that was classified as moderate-very fast $(7.50$ $-40.26 \mathrm{~cm} \mathrm{hr}^{-1}$ ) was higher than on agriculture land ( 0.75 to $17.96 \mathrm{~cm} \mathrm{hr}^{-1}$ (young cacao), $1.02-2.05 \mathrm{~cm}$ $\mathrm{hr}^{-1}$ (medium cocoa), 0.015-3.00 $\mathrm{cm} \mathrm{hr}^{-1}$ (old cocoa), and 4.44 to $9.00 \mathrm{~cm} \mathrm{hr}^{-1}$ (maize + peanut)) (Hidayat et al. 2008). Performance of surface runoff in several rain days is presented in Figure 1 and 2.

Ground clearing and tillage activities at the time of planting agriculture crops as well as weeding and maintenance activities of plants (bunding surrounding plant stands) were the major cause of high soil erosion on intercropping maize + peanut, maize, and intercropping young cocoa maize + cassava. It was consistent with the research result of Roose (1986) who showed that clearing of forests (clear felling system) led to increase soil erosion by more than 10-folds.

\section{Nutrient Loss in Transported Sediments}

\section{Soil Organic Carbon and Total Nitrogen}

Soil organic carbon in transported sediment from forest land was $1.7-4.4$ times higher than from agriculture land ones. However, the amount of soil organic carbon lost from agriculture land was higher (1.6 to 5.3 times) than forest land. The same pattern was also observed in total nitrogen, where 


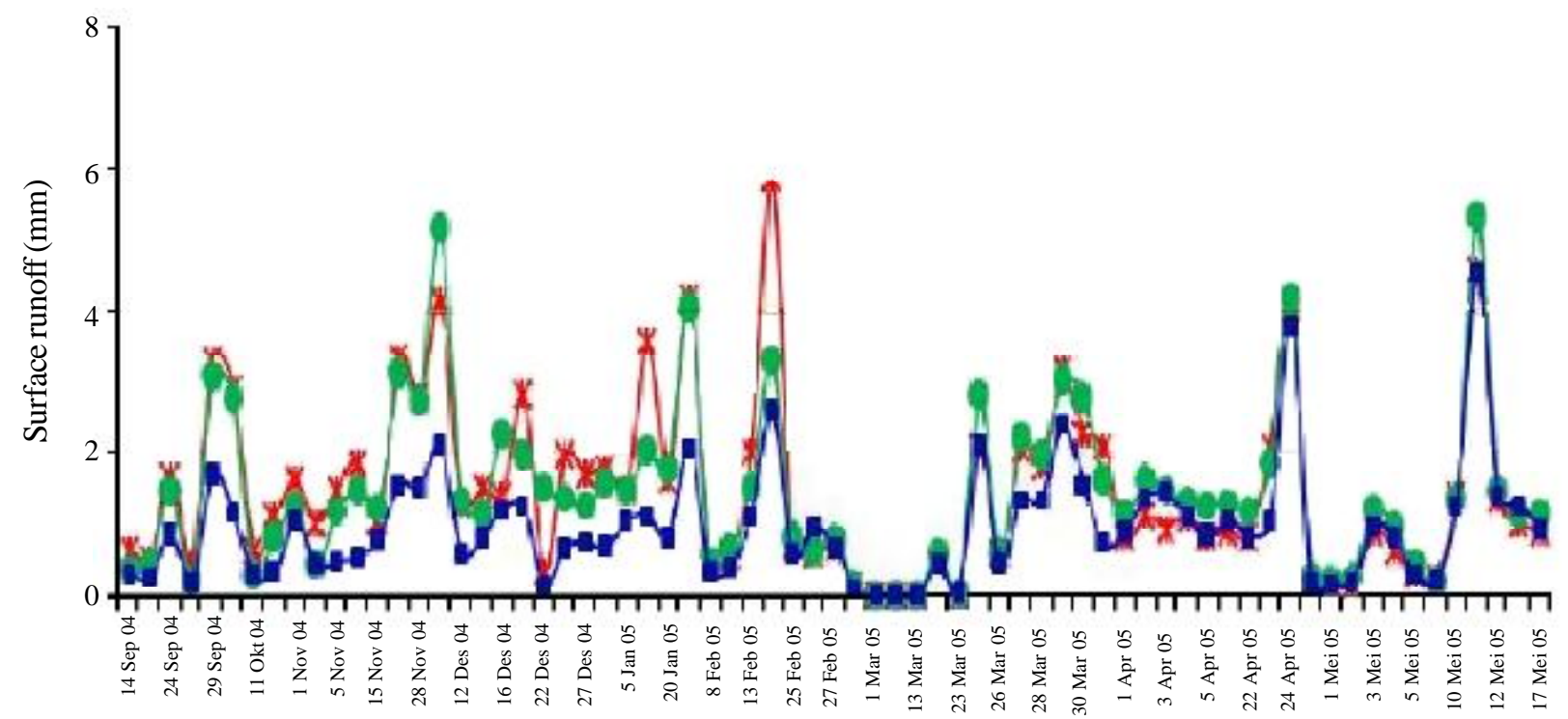

Figure 2. Surface run off from young, medium and old cocoas (September 2004-May 2005). - $-=$ young cocoa, $\longrightarrow=$ medium cocoa, and $\longrightarrow-=$ old cocoa.

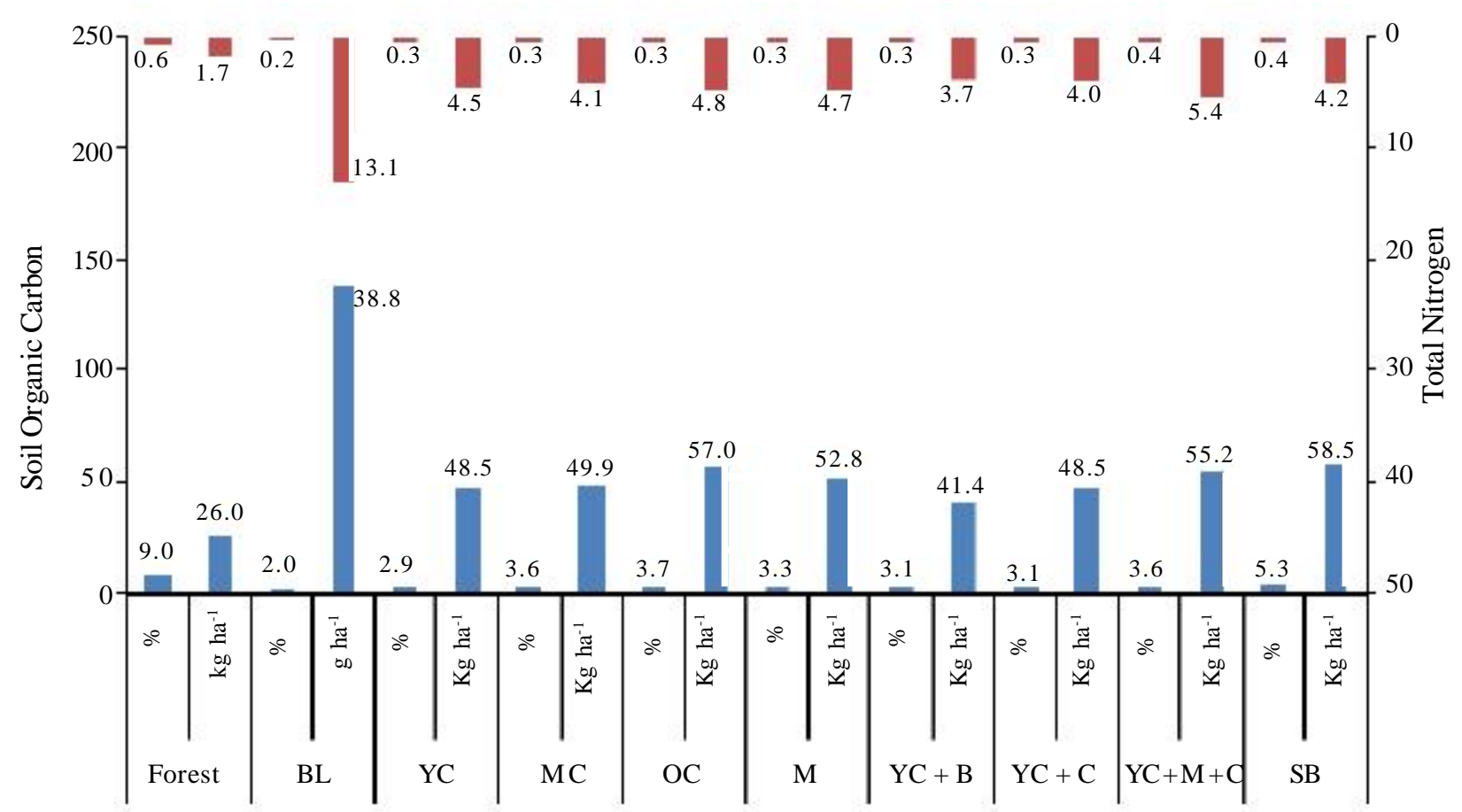

Figure 3. Soil organic carbon and total nitrogen losses carried by sediment from forest land (Forest), bareland (BL), young cocoa (YC), medium cocoa (MC), old cocoa (OC), maize (M), young cocoa + banana $(\mathrm{YC}+\mathrm{B})$, young cocoa + cassava $(\mathrm{YC}+\mathrm{C})$, young cocoa + maize + cassava $(\mathrm{YC}+\mathrm{M}+\mathrm{C})$, and shrub and bush $(\mathrm{SB})$.

total nitrogen levels in sediment from forest land was 1.6 to 3.1 higher than agriculture land. Conversely, the total loss of nitrogen from agriculture land was 2.1 to 7.5 times higher than forest land (Figure 3).

The high levels of soil organic carbon and total nitrogen in the sediment of forest land were due to it's fine texture sediment (clay) and the large amount of litter and other organic materials that had been decomposed in forest floor. Conversely sediment derived from bareland was more coarse-textured (sand) and it had low level of organic matter and other nutrients. Although the levels of organic carbon was high, the amount of soil organic carbon and total nitrogen lost from forest land were much lower than the agriculture and bareland. Loss of total soil organic carbon from forest land was $26.4 \mathrm{~kg} \mathrm{ha}^{-1}$ and it only occupied about $18.8 \%$ of total soil organic carbon lost from bareland. 
Potassium, Calcium, Magnesium and Sodium

Potassium, calcium, magnesium and sodium contents in transported sediments from forest land were $3.91,38.8,8.47$, and $0.8 \mathrm{cmol} \mathrm{kg}^{-1}$ respectively that were much higher than those contents in the bareland, i.e. $0.54,8.97,1.64$ and $0.57 \mathrm{cmol} \mathrm{kg}^{-1}$. Total potassium, calcium, magnesium and sodium lost by soil erosion from bareland respectively $1.44,12.26,1.36$, and 0.89 $\mathrm{kg} \mathrm{ha}^{-1}$ were higher than total nutrients losses from forest land that were $0.44,2.22,0.30$, and $0.04 \mathrm{~kg} \mathrm{ha}^{-1}$. In other words, converting of forest land into bareland caused increasing loss of potassium, calcium, magnesium and sodium respectively $326.2,552.6,457.3$, and $2303.4 \%$.
The same pattern was noted for agriculture lands (Figure 4).

Selectivity of soil erosion which mostly transported fine soil particles and colloidal size of organic matter (lighter) caused nutrient content in transforted sediments were higher than in the origin soil (top soil). The increase of nutrients content in sediment were highest on forest land but lowest on bareland. Soil organic carbon in transported sediment from forest land $(9.02 \%)$ increased 2.8 times compared to the soil organic carbon of topsoil ( $0-10$ $\mathrm{cm})$, i.e. $3.23 \%$. Total nitrogen and potassium also increased by 2.1 and 2.5 times. The increasing of nutrient contents in transported sediments occurred in bareland, young cocoa, medium cocoa, maize, young cocoa + maize + cassava (Figure 5 ) .

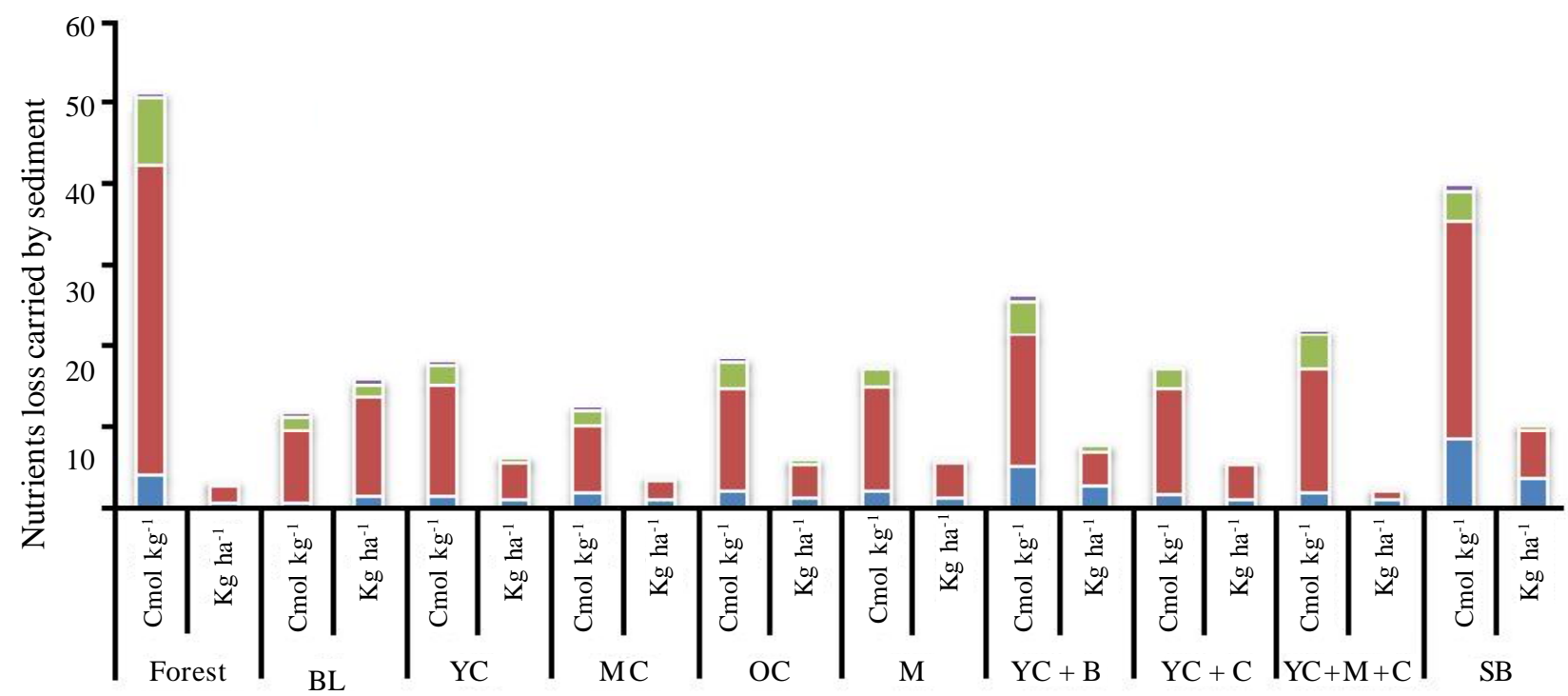

Figure 4. Potassium, calsium, magnesium and sodium loss carried by sediment from forest land (Forest), bareland (BL), young cocoa (YC), medium cocoa (MC), old cocoa $(\mathrm{OC})$, maize $(\mathrm{M})$, young cocoa + banana $(\mathrm{YC}+\mathrm{B})$, young cocoa+cassava $(\mathrm{YC}+\mathrm{C})$, young cocoa + maize + cassava $(\mathrm{YC}+\mathrm{M}+\mathrm{C})$, and shrub and bush $(\mathrm{SB})$.

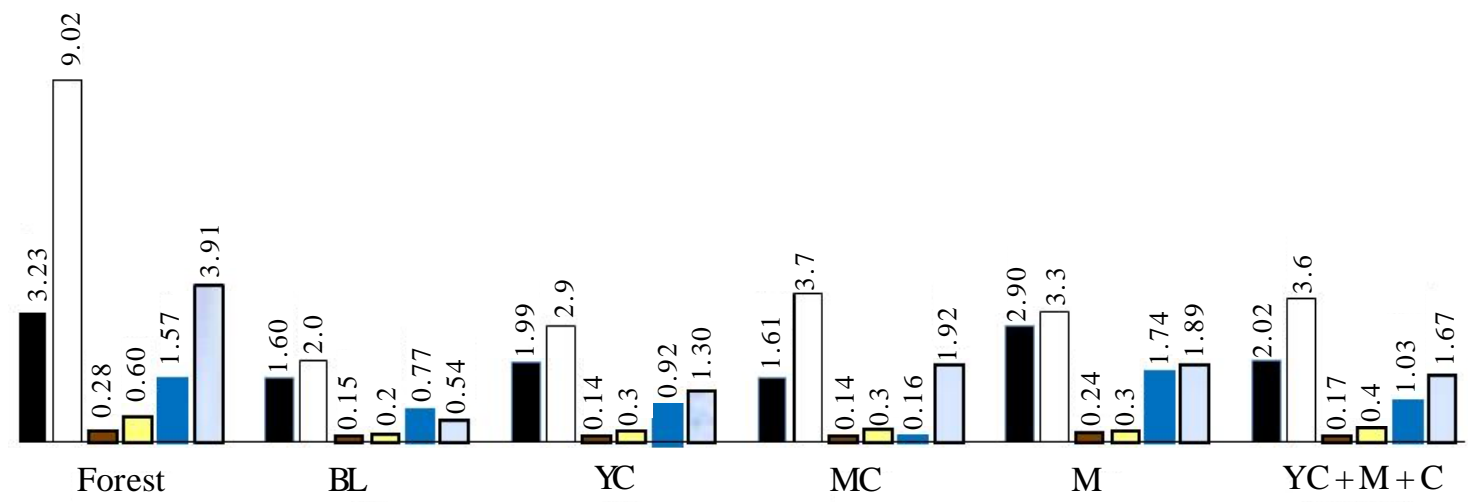

Figure 5. Soil organic carbon $(\% \mathrm{C})$, total nitrogen $(\% \mathrm{~N})$, and potassium $\left(\mathrm{cmol} \mathrm{kg}^{-1} \mathrm{~K}\right)$ in topsoil $(0-10$ $\mathrm{cm}$ ) and sediments from forest land (Forest), bareland (BL), young cocoa (YC), medium cocoa (MC), maize $(M)$, and intercropping young cocoa+maize+cassava $(\mathrm{YC}+\mathrm{M}+\mathrm{C})$. 


\section{Nutrients Loss in Surface Runoff}

\section{Dissolved Carbon}

Surface runoff that flows above soil surface transports dissolved nutrients which in turn lead to nutrient loss from the soil (especially agriculture land). Dissloved nutrients then enter into the water bodies and cause nutrients enrichment of the water system (eutrophication). Dissolved organic carbon (DOC) is a major loss of carbon compounds carried by the flow of surface runoff. Compared to dissolved inorganic carbon (DIC), the proportion of DOC was average $74 \%$, while the DIC is about 26\% (Figure 6). The highest DOC concentrations was found in forest lands, i.e. $57.12 \mathrm{mg} \mathrm{l}^{-1}$, and the lowest $\left(0.10 \mathrm{mg} \mathrm{l}^{-1}\right)$ was in intercropping young cocoa + maize + peanut. Moore et al. (2008) showed DOC concentrations of leachate from incubated soil (forest soil and peat soil) ranged from less than $2 \mathrm{mg} \mathrm{l}^{-1}$ to more than $50 \mathrm{mg} \mathrm{l}^{-1}$.

Loss of carbon carried by flow of surface runoff (DC) was higher than its loss by transported sediment (TOC, total soil organic carbon). Comparison of DC to TOC were 6.1 times on the maize and 8.0 times on forest land (Figure 7).

\section{Nitrate $\left(\mathrm{NO}_{3}^{-}\right)$}

Nitrate is a major loss of nitrogen compound transported by surface runoff. Loss of nitrate from agriculture land was 2.0 to 14.2 times higher than forest land. The highest nitrate loss was obtained on intercoping of young cocoa + cassava + maize $(\mathrm{YC}+\mathrm{M}+\mathrm{C})$, i.e. $65.7 \mathrm{~kg} \mathrm{ha}^{-1}$. Loss of nitrogen transported by surface runoff (NO3-) was 1.9 to 12.1 times higher than its loss carried by sediments (total nitrogen/TN) (Figure 8).

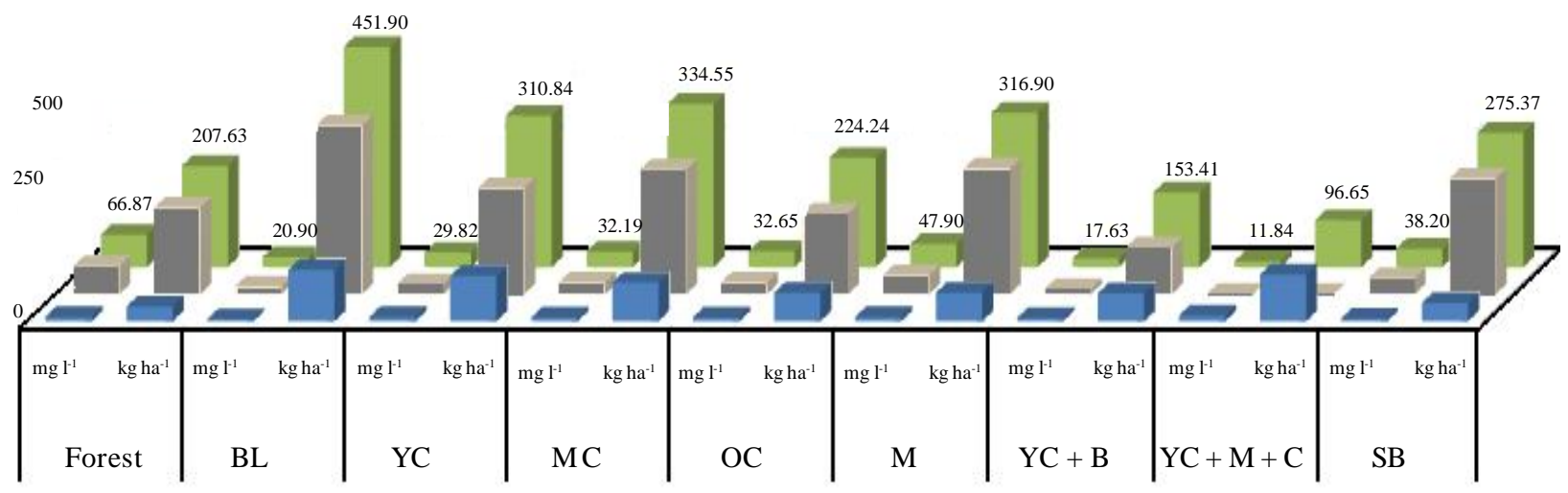

Figure 6. Dissolved inorganic carbons ( $\square$ ), dissolved organic carbons ( $)$, and total dissolved carbons $(\square)$ in surface runoff on forest land (Forest), bareland (BL), young cocoa (YC), medium cocoa (MC), old cocoa $(\mathrm{OC})$, maize $(\mathrm{M})$, young cocoa + banana $(\mathrm{YC}+\mathrm{B})$, young cocoa + maize + cassava $(\mathrm{YC}+\mathrm{M}+\mathrm{C})$, and shrubs and bush $(\mathrm{SB})$.

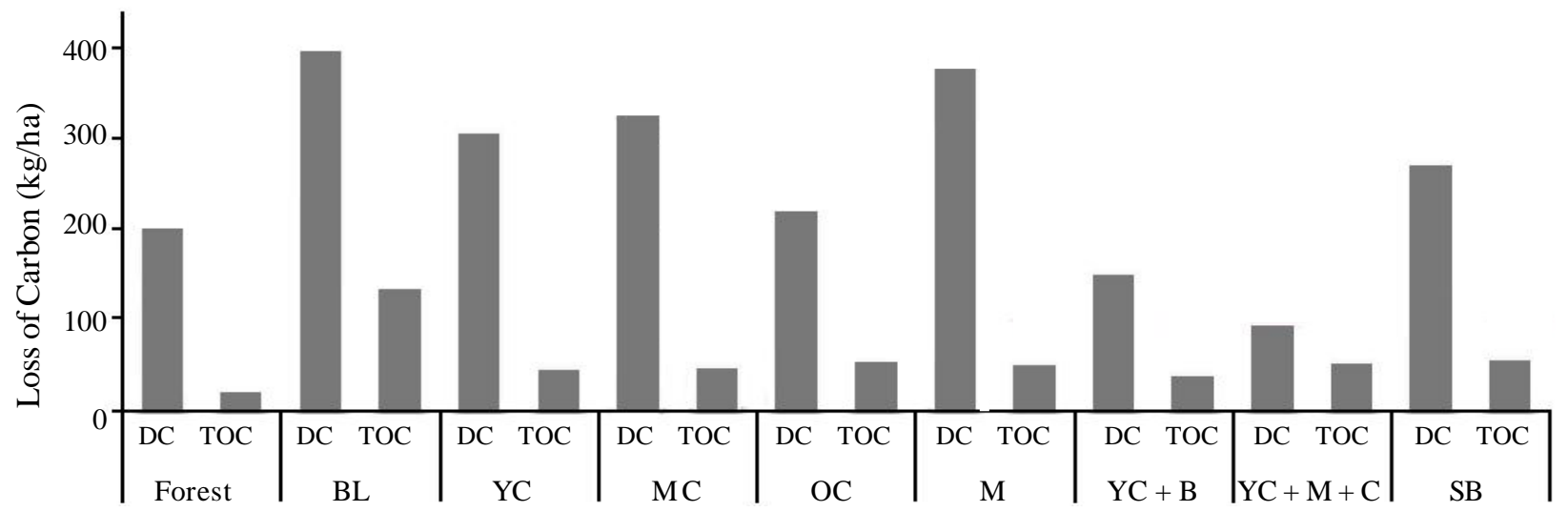

Figure 7. Dissolved carbon (DC) carried by flow of surface runoff and total soil organic carbon (TOC) transforted by sediment from forest land (Forest), bareland (BL), young cocoa (YC), medium cocoa $(\mathrm{MC})$, old cocoa $(\mathrm{OC})$, maize $(\mathrm{M})$, young cocoa+banana $(\mathrm{YC}+\mathrm{B})$, young cocoa + maize + cassava $(\mathrm{YC}+\mathrm{M}+\mathrm{C})$, and shrub and bush $(\mathrm{SB})$. 


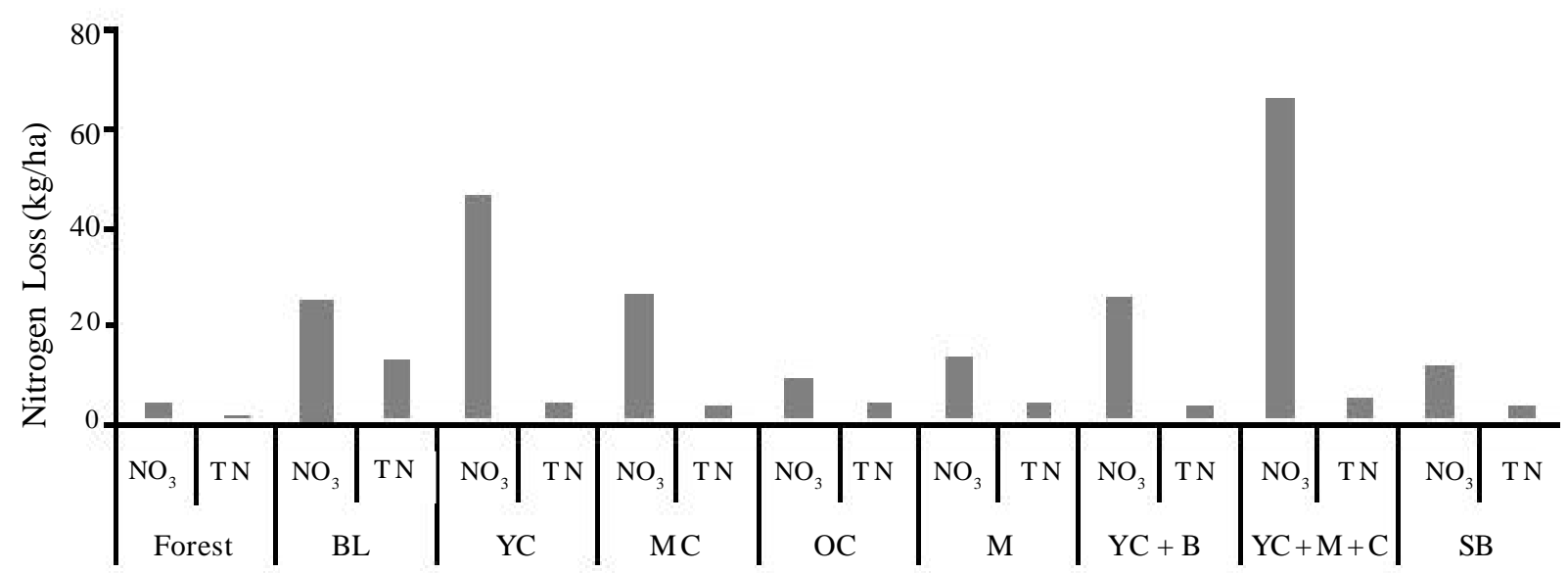

Figure 8. Loss of nitrogen carried by surface runoff $\left(\mathrm{NO}_{3}^{-}\right)$and transforted by sediment (TN) from forest land (Forest), bareland (BL), young cocoa (YC), medium cocoa (MC), old cocoa (OC), maize $(\mathrm{M})$, young cocoa+banana $(\mathrm{YC}+\mathrm{B})$, young cocoa+maize+cassava $(\mathrm{YC}+\mathrm{M}+\mathrm{C})$ and shrub and bush (SB).

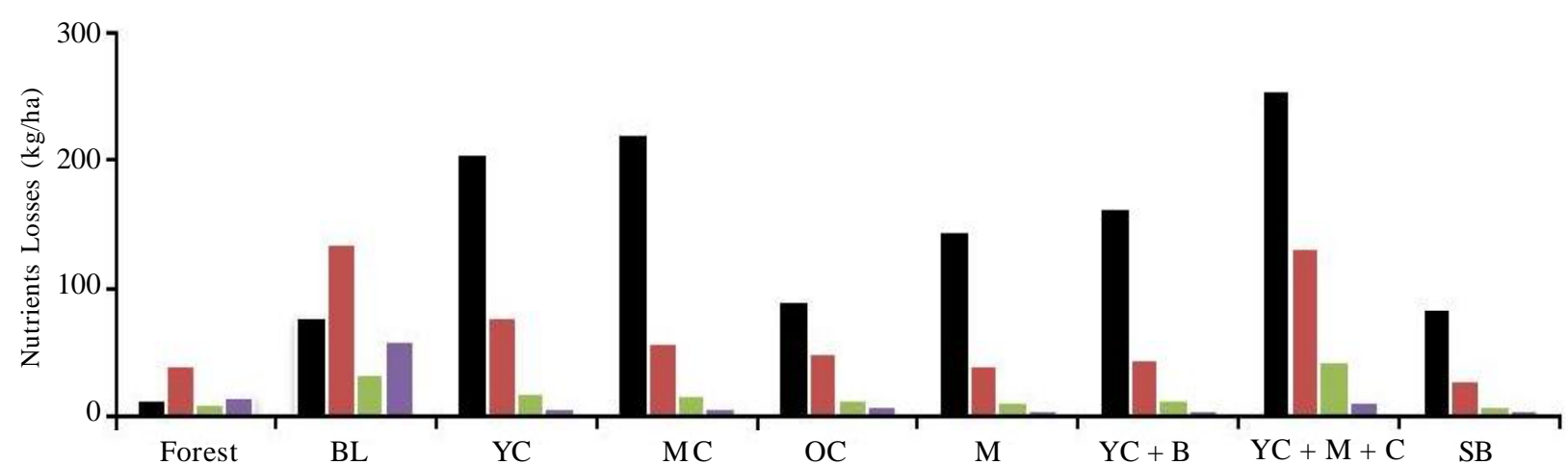

Figure 9. Loss of potassium, calcium, magnecium and sodium transforted by surface runoff from forest land (Forest), bareland (BL), young cocoa (YC), medium cocoa (MC), old cocoa (OC), maize (M), young cocoa + banana $(\mathrm{YC}+\mathrm{B})$, young cocoa + maize + cassava $(\mathrm{YC}+\mathrm{M}+\mathrm{C})$, and shrub and bush (SB).

\section{Potassium, Calcium, Magnesium and Sodium}

Potassium is the main base cation loss carried by flow of surface runoff. The highest potassium loss was $255.5 \mathrm{~kg} \mathrm{ha}^{-1}$ namely in intercropping young cocoa + maize + cassava, but the lowest was $12.6 \mathrm{~kg} \mathrm{ha}^{-1}$ on the forest land (Figure 9). Potassium content in top soil was relatively high that resulted from burned materials (wood, shrub, plant litter, and other organic materials above ground surface). Potassium is easily carried by surface runoff because its bound on soil particle more weakly compared to calcium and magnecium. Loss of potassium, calcium, magnesium and sodium transported by surface runoff are higher than it was loss carried by sediments (Hidayat et al. 2010).

\section{CONCLUSIONS}

Surface runoff and soil erosion from agriculture land were higher than forest land. Low rainfall interception due to low plant canopy cover and low infiltration rate were the major cause of high surface runoff and soil erosion on agriculture land. Concentrations of nutrients lost were inversely proportional to the surface runoff and soil erosion volume.

Nutrients content on transported sediment from forest land were higher than agriculture land, but total nutrients loss from forest land were farly less than agriculture land.

Nutrients loss carried by flow of surface runoff were higher than transported sediments ie. carbon, nitrogen, potassium, calcium, magnecium, and sodium. 


\section{ACKNOWLEDGEMENTS}

Thanks go to the STORMA (stability for rain forest margin) Project especially to Prof. Gerhard Gerold as chairman of the Sub Project B2 who has provided financial assistance, field research facility and laboratory analysis.

\section{REFERENCES}

Barisas SG, JLBaker, HP Johnson and JM Laflen. 1978. Effect of tillage systems on runoff losses of nutrients, a rainfall simulation study. TAm Soc Agric Eng 21: 893-897.

Bertol I, EL Mello, JC Guadagnin, ALV Zaparolli, and MR Carrafa. 2003. Nutrient Losses by Water Erosion. Sci Agric 60: 581-586.

Burwell RE, DR Timons and RF Holt. 1975. Nutrient transfort in surface runoff as influenced by soil cover and seasonal periods. Soil Sci Soc Am Proc 39:523-528.

Gascho GJ, RD Wauchope, JG Davis, CC Truman, CC Dowler, JE Hook, HR Sumner and AW Johnson. 1998. Nitrate-nitrogen, soluble, and bioavailable phosphorus runoff from simulated rainfall after fertilizer application. Soil Sci Soc Am J 62: 1711-1718.

Hidayat Y, N Sinukaban, H Pawitan and SD Tarigan. 2008. Dampak perambahan hutan terhadap aliran permukaan dan erosi di DAS Nopu Hulu, Sulawesi Tengah. J Trop Soils 13: 59-65 (in Indonesian).
Hidayat Y. 2009. Modifikasi factor tanaman dalam model ANSWERS. [Disertasi] Sekolah Pascasarjana IPB. Bogor. 169 p. (in Indonesian)

Hidayat Y, N Sinukaban, PHidayat and K Murtilaksono. 2010. Modifikasi faktor tanaman dalam model ANSWERS untuk memprediksi erosi di daerah tropika basah (Studi kasus DAS Nopu Hulu, Sulawesi Tengah). J Tanah Iklim 32: 43-53 (in Indonesian).

Johnson AH, JL Baker, WD Shrader and JM Laflen. 1979. Tillage system effect on sediment and nutrients in runoff from small watersheds. $T A m$ Soc Agric Eng 22: 1110-1114.

King KW, CW Richardson and JR Willians. 1996. Simulation of sediment and nitrate loss on a vertissol with conservation practices. TAm Soc Agric Eng 39: 2139-2145.

Moore TT, D Pare and R Boutin. 2008. Production of dissolved organic carbon in Canadian Forest Soil. Ecosystems 11: 740-751.

Roose EJ. 1986. Runoff and erosion before and after clearing depending on the type of crop in western Africa. In: R Lal, PA Sanchez and RW Cummings $\mathrm{Jr}$ (eds). Land Clearing and Development in the Tropics. AABalkema/Rotterdam/Boston, pp. 317330.

Sudjana. 1992. Metoda Statistika. Edisi kelima. Transito. Bandung (in Indonesian). 